\title{
Interaction Between Energy Distribution Systems and Urban Afforestation in the Metropolitan Region of Belo Horizonte
}

\author{
Rafael Malfitano Braga ${ }^{1}$ (D) \\ Francisco de Assis Braga ${ }^{2}$ (D) \\ Nelson Venturin ${ }^{1}$ \\ Marina Moura de Souza ${ }^{3}$
}

\begin{abstract}
Urban growth promotes changes in the environment and in the quality of life. Urban afforestation enables environmental services. But afforestation requires planning and maintenance to avoid conflicts with other urban equipment. The objective of this work was to analyze the interaction between urban afforestation and energy distribution systems in the Metropolitan Region of Belo Horizonte. The state-owned energy concessionaire's database was used, seeking to analyze the relationship between the history of outages in energy supply and the environmental factors associated with the fact, in the period between 2010 and 2015. It was found that the most relevant factors were the type of electrical energy distribution system (bare or isolated) and the maintenance (pruning) of the trees. The size of the tree and the strength of the wood are decisive in defining the demand for maintenance pruning to ensure a harmonious relationship between the trees and the electrical energy distribution system.
\end{abstract}

Keywords: landscaping, urban forests, urban trees.

\section{INTRODUCTION AND OBJECTIVES}

Contemporary society promotes significant interventions in the environment. The process of population concentration in cities promotes separation and an apparent loss of link between human beings and nature. The current model of urbanization prioritizes buildings and generates a gradual loss of vegetation cover, with negative impacts on environmental quality, health and citizens' lives (Soares et al., 2011). In view of this reality, it is essential to seek alternatives to improve the urban environment, combining concentration and demographic expansion with the quality of life and environment in contemporary cities (Fontoura, 2011).

In this context, parks and green areas, afforestation and urban forests provide the mitigation of negative impacts of the urbanization process, providing essential environmental services, such as air quality, microclimate stability, thermal comfort, reduction of noise pollution, spaces for leisure and contemplation, refuge and food for the fauna (Gómez-Baggethun \& Barton, 2013). However, urban afforestation requires careful planning to minimize costs, the need for interventions and the risk of conflicts between trees and other urban structures (Melo \& Severo, 2010).

Most Brazilian cities do not have a specific body to deal with the planning and management of urban afforestation, which causes several problems resulting from conflicts with urban structures (Santos et al., 2015; Duarte et al., 2018). Among urban structures, the electricity distribution system and public lighting have the greatest potential for interaction with urban trees (CEMIG, 2011). The interaction between the energy distribution system and the planning and maintenance of urban trees becomes crucial for the safety of the electrical system, reducing the risk of accidents and outages in the supply of energy and lighting (Velasco et al., 2006).

Historically, the conflicting relationship between outages in the supply of electricity and urban afforestation demonstrates the need for studies of the causes and solutions to this problem (Carmelo et al., 2005; Soares et al., 2011; Oliveira et al., 2013).

The objective of this work was to study the interaction between urban trees and energy distribution systems,

\footnotetext{
${ }^{1}$ Universidade Federal de Lavras (UFLA), Departamento de Ciências Florestais, Lavras, MG, Brasil.

${ }^{2}$ Universidade Federal de Viçosa, Florestal, MG, Brasil.

${ }^{3}$ Companhia Energética de Minas Gerais (CEMIG), Belo Horizonte, MG, Brasil.
} 
seeking to identify the most relevant urban afforestation factors in outages in the supply of electricity. It is expected that in places with a higher incidence of unprotected electrical system, with a higher density of afforestation, a lower maintenance rates and larger species with wood with less mechanical resistance, will be a greater number of shutdown events.

\section{MATERIALS AND METHODS}

\subsection{Study area}

The work was developed in the metropolitan region of Belo Horizonte (MRBH), capital of the state of Minas Gerais, with an area of $331 \mathrm{~km}^{2}$ (IBGE, 2013). Belo Horizonte is one of the most wooded capitals in Brazil, with around 600 thousand urban trees on the sidewalks alone, in addition to several green areas, parks and private gardens, accounting for an Index of Green Areas above $12 \mathrm{~m}^{2}$ per inhabitant, very relevant value from the point of view of urban quality (Lucon et al., 2019).

\subsection{Electrical distribution systems}

At MRBH overhead power distribution systems with conductive cables without electrical insulation predominate. This system is connected to approximately 400 distribution feeders, one third of which are in urban areas. These feeders are individualized circuits or branches, which conduct electricity from the distribution substations to the final consumer (CEMIG, 2011).

\subsection{Analysis of the history of outages in the supply of electricity}

The analysis of the history started with an exploratory study to assess the characteristics of the energy distribution systems and the information available in the database of Companhia Energética de Minas Gerais - CEMIG, MRBH's state power supply concessionaire. The data spreadsheets were selected considering complete information in terms of the extension of the electrical energy distribution system, type of distribution system, density of trees per $\mathrm{km}$ of distribution system and afforestation species close to the distribution lines and historical record of energy outages.

Of the total of around 400 distribution feeders in the MRBH, 142 were selected for sampling purposes, considering the most complete systems in the company's database, and excluding extensions that were substantially rural.
The outage history was evaluated between 2010 and 2015, considering the 13 shutdown causes for the power disconnections, used in the concessionaire's database: collisions, birds, animals, kites, ball, other objects in the energy distribution system, civil works, industrial causes, fires, vandalism, hidden threads, tree pruning performed by third parties and, finally, the interaction with afforestation (tree-cause).

The data of frequency of outages was processed to obtain the percentage annual historical evolution, highlighting the relative importance of each of the 13 causes over the period evaluated.

\subsection{Analysis of the interactions between the power grid and the outages caused by trees}

To assess the relationships between trees/palms and power outages, only incidents caused by the tree-factor were filtered in the database. The annual frequency of outages was evaluated considering the causative factors: tree density (number of trees per linear extension of the energy distribution system - data of trees in available in CEMIG's current arboreal inventory), type of energy distribution system (\% of bare or isolated system), tree size (small, medium and large) and pruning intensity (between 10 and $30 \%$ of approximate volume pruned crown). As each distribution feeder has a variable length, the frequency of disconnections per kilometer of electrical system was adopted.

In urban areas, variations in the electricity distribution system are commonly observed, which include aerial and underground networks, with electrically isolated cabling or not. The most common types in Brazilian cities are aerial systems (Figure 1): with protected or isolated cables (A) or with bare cables (B).

As for the size of the trees/palms, the criterion adopted by CEMIG (2011) for classification is: small = height does not reach the low voltage energy distribution system, that is, less than $6.2 \mathrm{~m}$; medium = height between low and medium voltage energy distribution systems, that is, between 6.2 and $8.5 \mathrm{~m}$; large = height above the wires of the medium voltage energy distribution system, that is, greater than $8.5 \mathrm{~m}$. These measurements are the total height.

Of the 142 feeders previously selected, thirty were sampled, configuring two contrast groups for each shutdown factor studied, that is, the first with the fifteen systems that presented the highest value for each factor and the second with the fifteen feeders with the lowest value. for each causal factor studied. 


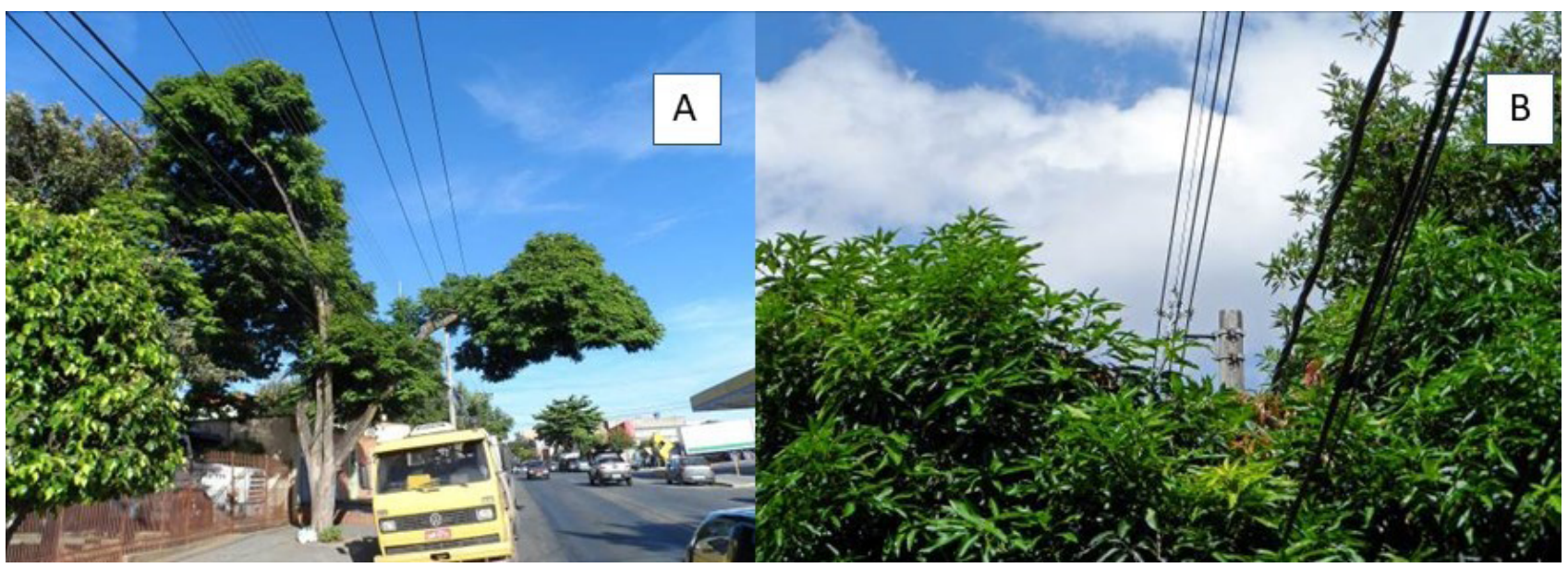

Figure 1. Energy distribution system types: bare and protected system (personal archive).

The relationship between tree species and the frequency of outages was assessed to identify possible dendrological characteristics associated with disconnections. For this purpose, the 10 species with the highest frequency in two contrasting conditions were considered: 15 energy distribution systems with the highest and 15 with the lowest shutdown frequency. Altogether more than 10,000 trees were computed in the study of species.

\subsection{Data processing and analysis}

The effect of each environmental factor on outages was verified by comparing the average shutdown values of the two contrast groups (higher and lower shutdown incidence), using the $t$ test, at the level of $5 \%$ probability.
The analyzes were performed of the SISVAR software (Ferreira, 2014).

\section{RESULTS AND DISCUSSION}

\subsection{Analysis of electrical outages due to environmental causes}

Analysis of outages due to shutdown causesin the CEMIG database for $\mathrm{MRBH}$ showed around 100 thousand outages in the supply of electrical energy in the period from 2010 to 2015. About $37.6 \%$ of these outages were due to interactions between the electricity grid and urban afforestation (Figure 2), demonstrating the relevance of this interaction in the energy supply, as also observed by Carmelo et al. (2005).

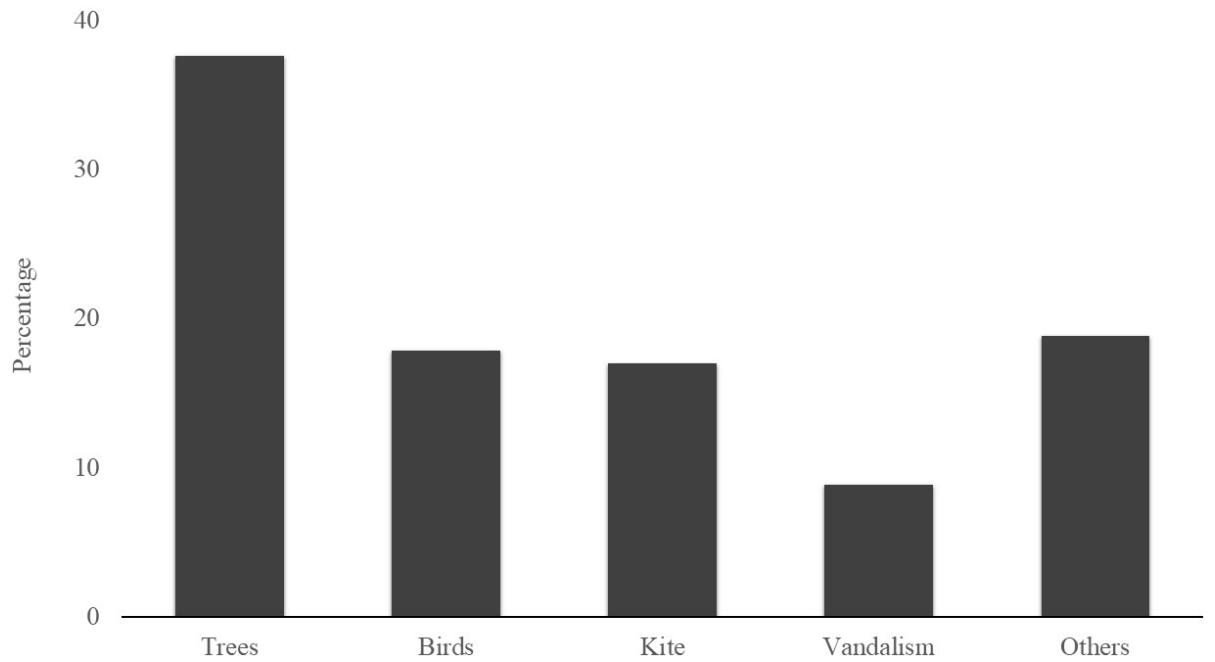

Figure 2. Percentage distribution of outages in the supply of electricity in the Metropolitan Region of Belo Horizonte, organized by cause, in the period from 2010 to 2015 . 
The annual history of energy outages caused by trees/ palms at MRBH (Figure 3) showed a continuous downward trend between 2010 and 2014, probably associated with the management of afforestation through regular pruning. Besides that, the years 2012 and 2013 were climatically atypical, with a record of low total precipitation and few intense rains at MRBH (INMET, 2014), which may also have contributed to reducing outages. However, the increase registered between 2014 and 2015 must be related with the reduction in maintenance, due to budget cuts in that period, according to internal information from CEMIG.

Considering only environmental causes, Carmelo et al. (2005) also observed outages of the order of $30 \%$ associated with the interaction of the electric energy distribution system with afforestation in the city of São Paulo. The same authors report that this value can reach 40 to $50 \%$, depending on local and climatic conditions, the extent of the wooded area and the inadequate management of pruning.

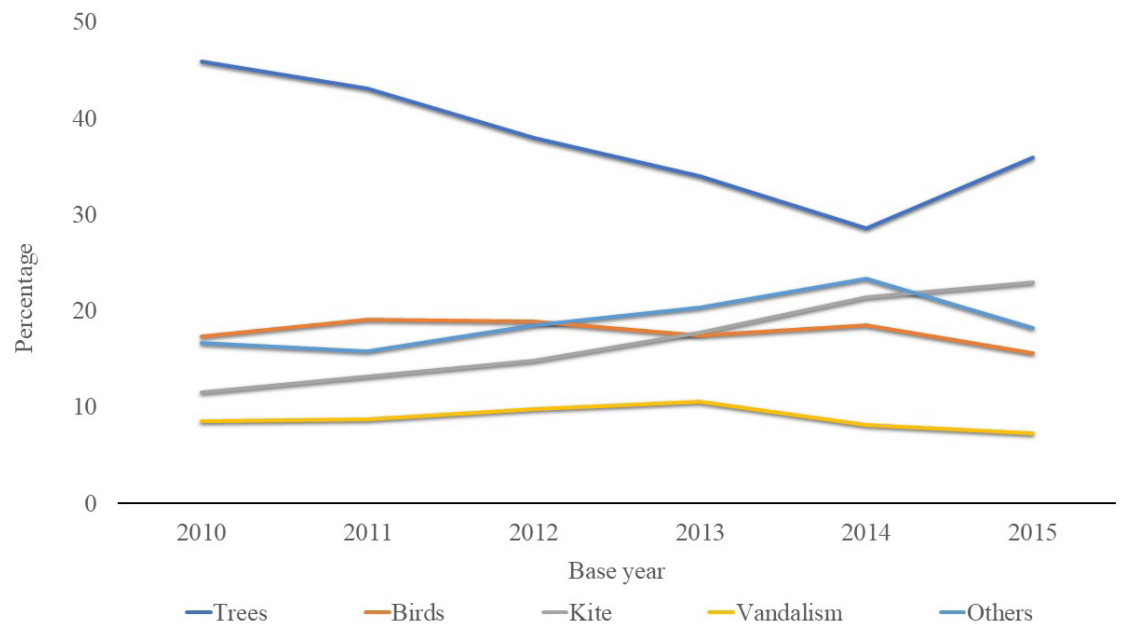

Figure 3. History of outages in the supply of electricity in the Metropolitan Region of Belo Horizonte, organized by the cause, in the period from 2010 to 2015.

\subsection{Analysis of electrical outages caused by afforestation}

The interaction between the electrical energy distribution system and urban afforestation (Table 1) was significant only for the pruning intensity and the type of energy distribution system (isolated or bare).

Although the general history of outages due to shutdown causesat MRBH has indicated that the interaction with afforestation is the main factor, as previously reported, it was found that the size and density of trees under the power grid did not have a relevant effect in the incidence of outages. Therefore, the mere presence or size of trees/palms does not directly cause conflicts in the electrical system, but yes, the effectively of management by pruning of the afforestation.

This result is extremely relevant, as it indicates that harmonious coexistence between energy distribution systems and afforestation in cities is possible, provided that regular pruning is carried out and / or that isolated cabling is used. Thus, it is perfectly plausible to implement and maintain afforestation under an electrical energy distribution system, enabling essential environmental services for environmental quality and life in cities (Gómez-Baggethun \&
Barton, 2013), provided that appropriate techniques are used in the management of trees (Althaus, 2005, Leal et al., 2008; São Paulo, 2011; Vogt et al., 2015).

On the other hand, the data show that the intensity of pruning applied to trees affects energy outages differently. Pruning reaching a higher percentage of crown generated higher incidence of outages compared to soft pruning. In the systems where pruning was carried out at an intensity greater than $30 \%$ of the tree crown, there was a higher incidence of outages.

Severe pruning is not recommended, as it promotes rapid and intense sprouting close to the cut, forming new long and ascending branches, called epicormic branches, that coming to interact with the power grid (Melo et al., 2019). Besides that, the speed of healing of pruning incisions is inversely proportional to the diameter of the cut branch, justifying pruning with small interventions again (Velasco et al., 2006).

Another important aspect concerns the costs and complexity of pruning management. Commonly, a lower percentage of pruned crown results in a lower operating cost (Melo et al., 2019). Therefore, more frequent pruning with smaller diameter incisions is recommended, optimizing management and cost and reducing the risk of outages (Burcham et al., 2019). 
Table 1. Average values of energy outages and coefficients of variation for energy distribution systems with higher and lower incidence of factors associated with afforestation in MRBH between 2010 and 2015.

\begin{tabular}{|c|c|c|c|}
\hline Factor Incidence & Outages (number / km of energy systems) & Coefficient of Variation (\%) & $\begin{array}{c}\text { Meaningfulness } \\
\text { (t-test) }\end{array}$ \\
\hline \multicolumn{4}{|l|}{ Tree density } \\
\hline High & 1.03 & 41.2 & $0,1205^{\mathrm{ns}}$ \\
\hline Low & 0.78 & 39.8 & \\
\hline \multicolumn{4}{|l|}{ Tree size } \\
\hline High & 0.84 & 44.1 & $0,9321^{\mathrm{ns}}$ \\
\hline Low & 0.86 & 45.4 & \\
\hline \multicolumn{4}{|c|}{ Percentage of crown pruned } \\
\hline High & 1.33 & 41.5 & $0.0003^{\star}$ \\
\hline Low & 0.64 & 34.2 & \\
\hline \multicolumn{4}{|c|}{ Percentage of bare distribution systems } \\
\hline High & 0.99 & 44.9 & $0.0208^{\star}$ \\
\hline Low & 0.46 & 40.3 & \\
\hline
\end{tabular}

* significant at $5 \%$ by $t$ test; ns not significant.

Considering the frequency of outages and the type of electrical energy distribution system, it is observed that systems with isolated cabling cut at least in the half of the number of disconnections. This fact demonstrates that bare nets do not provide adequate protection to the conducting wires, leaving them susceptible to interaction with trees and the consequent outage of energy (Carmelo et al., 2005; Velasco et al., 2006; Leal et al.2008; Vogt et al., 2015).

Another important point concerns the lower demand for pruning on trees under isolated energy distribution systems, considering that the isolated cabling allows a certain degree of contact and physical interaction with the crown of trees without great risks to the system, that is, the pruned crown area can be smaller under isolated energy distribution systems (Velasco et al., 2006; Leal et al.2008).

Therefore, the substitution of bare conductors for isolated ones should be one of the priorities in energy distribution energy distribution systems over afforestation (Leal et al., 2008), aiming not only to reduce the frequency of outages, but also the frequency and intensity of the operations of pruning, as well as the costs of maintaining afforestation, providing a better interaction between the treetops and the energy distribution system (Oliveira et al., 2013).

The use or replacement of unprotected energy distribution systems with compact and protected energy distribution systems in cities is totally feasible, as it reduces the cost of maintaining energy distribution systems and trees by up to $80 \%$ in the long term (Velasco et al., 2006).

Despite its importance in the landscape, the urban afforestation in Brazil is still a challenge to be overcome. The lack of clear policies related to its implementation and management in most Brazilian municipalities according to local needs and specificities is a clear reflection of the need for advances in this sector (Duarte et al., 2018).

\subsection{Tree species and their interaction with energy distribution systems}

When comparing the 15 energy distribution systems with the highest and lowest frequency of shutdowns in the MRBH, the 10 tree species found in each condition have different dendrological characteristics (Figures 4 and 5, Table 2).

Under the distribution systems with the highest frequency of outages, large species (Sibipiruna, Mangueira, Angico-Vermelho, Aroeira-do-Sertão, Eucalipto and Ipê-Rosado), medium-sized (Quaresmeira and Jacaré) and palm trees were found (Imperial and Licuri). This variation in the size of the species also occurred under energy distribution systems with less frequency of disconnections, being large species (Sibipiruna, Castanheira, Oiti, Ficus-Benjamim, Munguba, Ipê-Rosado and Mangueira) and medium-sized (Alfeneiro, Pata-de-Vaca and Leucena), but without the presence of palm trees.

The fact that palm trees are found only under nets with more frequent outages indicates that this group of plants may be more directly involved in disconnections. Palm trees is a group of plants for which there are no pruning and handling techniques, but only the removal of senescent leaves. It is worth mentioning that the leaves of the imperial and licuri palm trees are large and heavy, which can cause physical damage to the urban structures, such as cable breaks and / or short circuits, causing a drop in the energy supply.

Other species found under energy distribution systems with higher frequency of disconnections were AngicoVermelho, Aroeira-do-Sertão, Eucalipto, Quaresmeira and Jacaré (Figure 4 and 5). Most of these are large trees, with wood of varying resistance, showing a low relationship between these dendrological characteristics and the frequency of outages. 


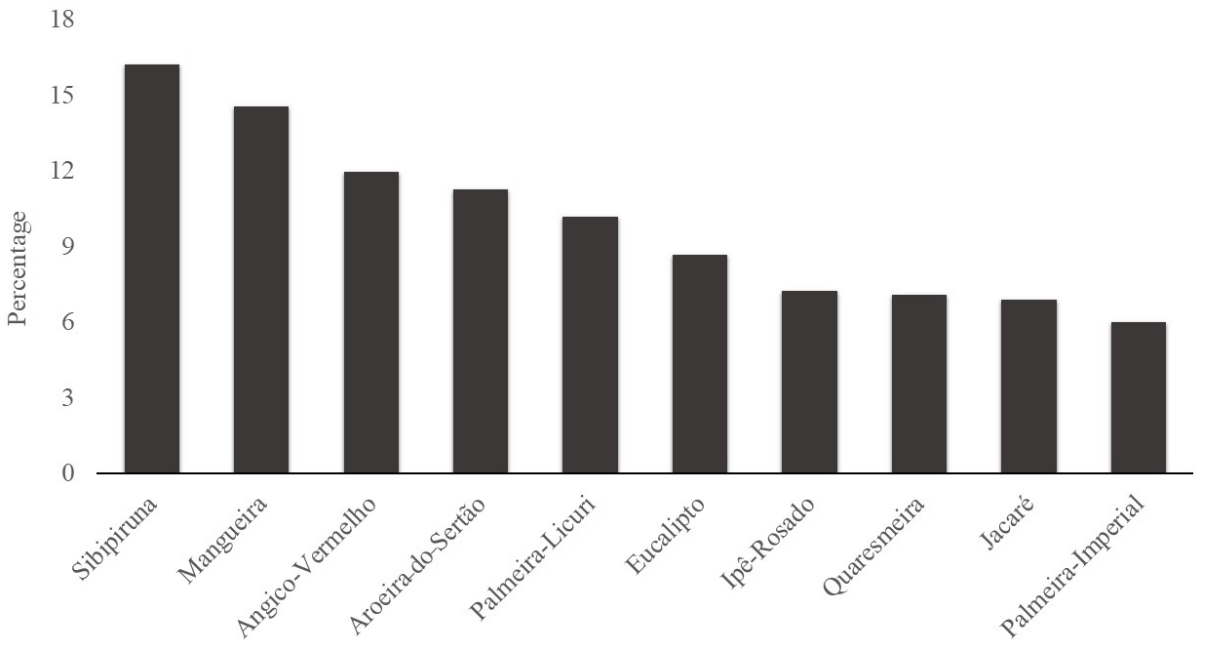

Figure 4. Percentage relationship of the ten most frequent tree species under energy distribution systems with the highest incidence of outages in the supply of energy in the MRBH.

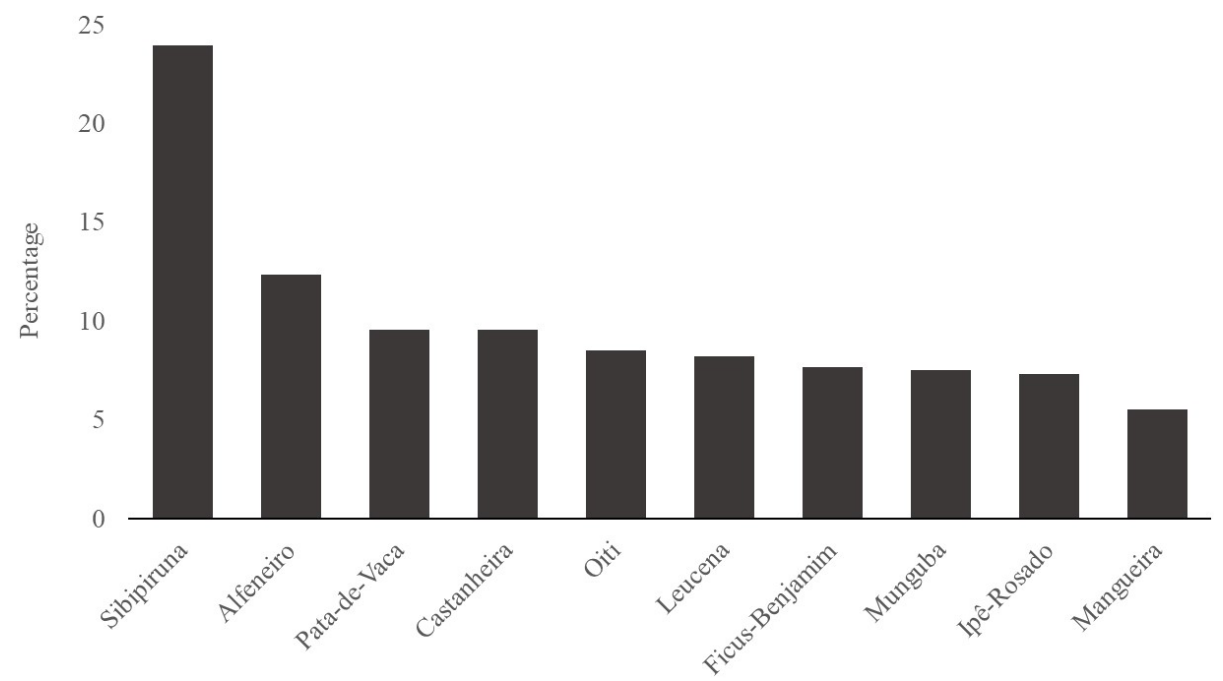

Figure 5. Percentage relationship of the ten most frequent tree species under energy distribution systems with the lowest incidence of outages in the energy supply at MRBH.

Table 2. Characteristics of the most frequent species in urban afforestation in MRBH.

\begin{tabular}{|c|c|c|c|c|}
\hline Popular Name & Scientific Name & Size & Wood & Ref. \\
\hline Alfeneiro & Ligustrum japonicum Thunb. & $\mathrm{M}$ & $\mathrm{M}$ & 4,6 \\
\hline Angico-Vermelho & Anadenanthera macrocarpa (Benth.) Brenan & $\mathrm{L}$ & M & 1,6 \\
\hline Aroeira-do-Sertão & Myracrodruon urundeuva Fr. All. & $\mathrm{L}$ & $\mathrm{H}$ & 3,6 \\
\hline Castanheira & Terminal catappa $\mathrm{L}$. & $\mathrm{L}$ & M & 3,6 \\
\hline Eucalipto & Eucalyptus e Corymbia spp. & $\mathrm{L}$ & M & 4,6 \\
\hline Ficus-Benjamim & Ficus benjamina L. & $\mathrm{L}$ & M & 4,6 \\
\hline Ipê-Rosado & Handroanthus heptaphyllus (Mart.) Mattos & $\mathrm{L}$ & $\mathrm{H}$ & 4,6 \\
\hline Jacaré & Piptadenia gonoacantha (Mart.) J. F. Macbr. & $\mathrm{M}$ & S & 2,6 \\
\hline Leucena & Leucaena leucocephala (Lam) de Wit. & $\mathrm{M}$ & S & 4,6 \\
\hline Mangueira & Mangifera indica L. & $\mathrm{L}$ & M & 4,6 \\
\hline Munguba & Pachira aquatica Aubl. & $\mathrm{L}$ & M & 3,6 \\
\hline Oiti & Licania tomentosa (Benth) Fritsch & $\mathrm{L}$ & $\mathrm{H}$ & 3,6 \\
\hline Palmeira-Imperial & Roystonea oleracea (Mart.) Cook. & $\mathrm{L}$ & M & 5 \\
\hline Palmeira-Licuri & Syagrus coronata (Mart.) Becc. & M & M & 5 \\
\hline Pata-de-Vaca & Bauhinia sp. & M & M & 2,6 \\
\hline Quaresmeira & Tibouchina granulosa (Desr.) Cong. & M & S & 1,6 \\
\hline Sibipiruna & Caesalpinia pluviosa Benth. & $\mathrm{L}$ & M & 1,6 \\
\hline
\end{tabular}

Size: $\mathrm{S}=$ short $(<6,2 \mathrm{~m}) ; \mathrm{M}=$ medium $(6,2-8,5 \mathrm{~m}) ; \mathrm{L}=$ large $(>8,5 \mathrm{~m})$. Wood resistance: $\mathrm{S}=$ soft; $\mathrm{M}=$ medium; $\mathrm{H}=$ high. Ref.: (1) Carvalho, 1994; (2) Lorenzi, 1998; (3) Lorenzi, 2002; (4) Lorenzi et al., 2003; (5) Lorenzi et al., 2004; (6) CEMIG, 2011. 
On the other hand, the following species appear in electrical systems with less outages: Alfeneiro, Pata-de-Vaca, Castanheira, Oiti, Leucena, Ficus-Benjamim and Munguba (Figure 4 and 5), also with distinct characteristics of size and resistence of the wood.

The presence of medium and large species in the different energy distribution systems indicates a low relationship between the size of the tree and the frequency of outages, signaling that the problem would be more related to the type of energy distribution system (isolated or bare) and the correct application of pruning, as previously reported. The in-depth knowledge of the species used in the urban environment and the appropriate pruning regime for each of them must be the focus of those who manage afforestation. The except is due to the palm trees, not recommended for planting under the distribution systems due to the impossibility of pruning (CEMIG, 2011; São Paulo, 2011).

Another point worth mentioning is the presence of species in both listings, such as Sibipiruna, Mangueira and Ipê-Rosado. This fact can be explained by the high planting frequency in RMBH, how as in other Brazilian municipalities. These species are very common and, therefore, have high representativeness in the data.

Finally, it is worth mentioning that the mechanical resistance of wood is a fundamental characteristic to reduce the risk of accidents involving urban trees, such as the breaking of branches (Vale et al., 2005). However, in the present study, species with higher and lower resistance wood were found under energy distribution systems with higher and lower frequency of disconnections, suggesting little direct relationship between the resistance of the wood and outages. However, it is worth noting that the mechanical resistance of wood, both in terms of basic density, and resistance to rotting by xylophagous agents is too important about maintenance practices, with emphasis on pruning (Burcham et al., 2019).

\section{CONCLUSIONS}

The interaction between the energy distribution systems and urban afforestation is basically determined by the type of distribution system (isolated or bare) and the maintenance (pruning) of the trees. The size and mechanical strength wood affect the potential for tree interference with the electrical system, defining, in this case, the demand for pruning to ensure a harmonious relationship between the feeders and the underlying afforestation.

\section{SUBMISSION STATUS}

Received: 9 June 2020

Accepted: 18 Aug. 2020

Associate editor: João Vicente Latorraca

\section{CORRESPONDENCE TO}

\section{Rafael Malfitano Braga}

Universidade Federal de Lavras,, Departamento de Ciências Florestais, Caixa Postal no 3037, CEP. 37200-000, Lavras, MG, Brasil. e-mail: rafael.malfitano@hotmail.com

\section{REFERENCES}

BURCHAM DC, AUTIO WR, JAMES K, MODARRES-SADEGHI Y, KANE B. Efeito do tipo de poda e gravidade nas propriedades de vibração e massa de mogno senegal (Khaya senegalensis) e árvore de chuva (Samaneasaman). Árvores 2019; 3(1):1-16.

CARMELO SR, ELETROPAULO AES, SEITZ RA. Diagnóstico das interferências de árvores na rede de distribuição aérea de energia elétrica. Curitiba: UFPR; 2005.

CARVALHO PER. Espécies Florestais Brasileiras - Recomendações Silviculturais, potencialidades e Usos da Madeira. Brasília: EMBRAPA - SPI; 1994.

COMPANHIA ENERGÉTICA DE MINAS GERAIS - CEMIG. Manual de arborização. Belo Horizonte: CEMIG/Fundação Biodiversitas; 2011.

DUARTE TEPN, ANGEOLETTO F, SANTOS JWMC, SILVA FF, BOHRER JFC, MASSAD L. Reflexões sobre arborização urbana: desafios a serem superados para o incremento da arborização urbana no Brasil. Revista em Agronegócio e Meio Ambiente 2018; 11(1): 327-341.

FERREIRA DF. SISVAR: a guide for its bootstrap procedures in multiple comparisons. Ciência e Agrotecnologia 2014; 38(2):109-112.

FONTOURA LFM. Campo, cidade e a natureza recriada na artificialidade urbana. Boletim Gaúcho de Geografia 2011; 36(1):43-51.

GÓMEZ-BAGGETHUN E, BARTON DN. Classificando e valorizando serviços ecossistêmicos para o planejamento urbano. Economia Ecológica 2013; 6(1)1;235-245.

INSTITUTO BRASILEIRO DE GEOGRAFIA E ESTATÍSTICA. Área Territorial Brasileira. Brasília: Resolução da Presidência do IBGE, n.5, 2013. [cited 2018 may. 10] Available from: http://www.ibge.gov.br/home/geociencias/cartografia/

INSTITUTO NACIONAL DE METEOROLOGIA-INMET. Boletim Agroclimatológico Mensal, v.47-48, 2014.

LEAL L, BIONDI D, ROCHADELLI R. Custos de implantação e manutenção da arborização de ruas da cidade de Curitiba, PR. Revista Árvore 2008; 32(3):557-565. 
LORENZI H. Árvores brasileiras: manual de identificação e cultivo de plantas arbóreas nativas do Brasil, v.2. 1 ed. Nova Odessa: Instituto Plantarum, 1998.

LORENZI H. Árvores brasileiras: manual de identificação e cultivo de plantas arbóreas nativas do Brasil, v.1. 2 ed. Nova Odessa: Instituto Plantarum, 2002.

LORENZI, H, SOUZA, H. M.; TORRES, M. A. V.; BACHER, L. B. Árvores exóticas no Brasil: madeireiras, ornamentais e aromáticas. 1 ed. Nova Odessa: Instituto Plantarum, 2003.

LORENZI, H; SOUZA, H. M.; FERREIRA, E.; CERQUEIRA, L. S. C.; COSTA, J. T. M. Palmeiras brasileiras e exóticas cultivadas. Nova Odessa-SP: Instituto Plantarum, 2004.

LUCON, T. N.; PRADO FILHO, J. F.; SOBREIRA, F. G. Índice e percentual de áreas verdes para o perímetro urbano de Ouro Preto-MG. Revista da Sociedade Brasileira de Arborização Urbana 2019; 8(3):63-78.

MELO EFRQ, SEVERO BMA. Avenida Brasil (Passo Fundo, Rio Grande do Sul): diversidade da vegetação e qualidade ambiental. Revista da Sociedade Brasileira de Arborização Urbana 2010; 5(3):1-17.

MELO RR, LIRA FILHO JA, JÚNIOR FR. Diagnóstico qualitativo e quantitativo da arborização urbana no bairro Bivar Olinto, Patos, Paraíba. Revista da Sociedade Brasileira de Arborização Urbana 2019; 2(1):64-80.

OLIVEIRA M, PERETTI C, BUDKE JC, SANTOS SC, CORAZZA T, GOMES S, et al. Reflexos da evolução urbana sobre a arborização em Erechim, Sul do Brasil. Revista da Sociedade Brasileira de Arborização Urbana 2013; 8(2):86-103.

PORTO LPM, BRASIL HMS. (Eds.) Manual de Orientação Técnica da Arborização Urbana de Belém: guia para planejamento, implantação e manutenção da arborização em logradouros públicos. Belém: Universidade Federal Rural da Amazônia, 2013.

SANTOS CZA, FERREIRA RA, SANTOS LR, SANTOS LI, GOMES SH, GRAÇA DAS. Análise qualitativa da arborização urbana de 25 vias públicas da cidade de Aracaju-SE. Ciência Florestal 2015; 25(3):751-763.

SÃO PAULO (Município). Manual Técnico de Arborização Urbana. 2.ed. São Paulo: SVMA/SMSP, 2011.

SOARES AL, REGOA FC, MCPHERSON EG, SIMPSON JR, PEPERB PJ, XIAO Q. Benefícios e custos de árvores de rua em Lisboa, Portugal. Floresta Urbana e Verde Urbano 2011; 10(2):69-78.

VALE AT, SARMENTO TR, ALMEIDA AN. Caracterização e uso de madeiras de galhos de árvores provenientes da arborização de Brasília, DF. Ciência Florestal 2005; 15(4):411-420.

VELASCO GN, LIMA AML, COUTO HTZ. Análise comparativa dos custos de diferentes redes de distribuição de energia elétrica no contexto da arborização urbana. Revista Árvore 2006; 30(4):679-686.

VOGT J, HAUER RJ, FISCHER BC. Os Custos de Manutenção e Não Manutenção da Floresta Urbana: Revisão da Literatura Florestal Urbana e Arboricultura. Arboricultura e Florestas Urbanas 2015; 41(6):293-323. 